\title{
Amyloid Alpha Precursor Protein Measurement
}

National Cancer Institute

\section{Source}

National Cancer Institute. Amyloid Alpha Precursor Protein Measurement. NCI

Thesaurus. Code C119268.

The determination of the amount of the amyloid alpha precursor protein in a biological specimen. 